\title{
Organoleptic Acceptability, Nutritional Properties and Shelf Life of Oat Based Gluten Free Instant idli
}

\author{
Bhawna Mehta* and Sudesh Jood \\ Department of Foods and Nutrition, College of Home-Science, CCS Haryana Agriculture \\ University, Hisar, Haryana, India \\ *Corresponding author
}

\begin{tabular}{|l|}
\hline Ke y w o r d s \\
$\begin{array}{l}\text { Instant mixes, } \\
\text { Organoleptic } \\
\text { acceptability, Nutritional } \\
\text { properties, Shelf life, Fat } \\
\text { acidity }\end{array}$ \\
\hline Article Info \\
\hline $\begin{array}{l}\text { Accepted: } \\
\text { 16 February } 2018 \\
\text { Available Online: } \\
\text { 10 March } 2018\end{array}$ \\
\hline
\end{tabular}

\section{A B S T R A C T}

Instant mixes are commercially prepared mixture of dry ingredients as these are easy and fast to prepare. Keeping these facts in view, in the present study five types of gluten free instant $i d l i$ were prepared by using instant mixes i.e., 40 per cent rice flour, 20 per cent mung bean flour and 5 per cent linseed powder in 60 per cent processed (malted, roasted, popped and flaked) and unprocessed oat flour. It was found that idli prepared from Type-I (unprocessed oat flour based blend), Type-II (malted oat flour based blend) and Type-III (flaked oat flour based blend) instant mixes fell in the category of 'liked moderately' whereas $i d l i$ prepared from Type-IV and Type-V instant mixes were found in the category of 'liked slightly' to 'neither liked nor disliked'. The most acceptable idli was selected for their nutritional composition and shelf life. Water and oil absorption capacity was significantly higher in Type-II idli as compared to Type-III and Type-I idli. Whereas, Type-I dhokla exhibited higher bulk density. Nutritional properties showed that Type-II (malted oat flour based blend) idli had maximum protein $(18.86 \%)$, carbohydrates $(68.21 \%)$ and energy $(389.95 \mathrm{Kcal} / 100 \mathrm{~g})$. Whereas, highest crude fibre $(7.22 \%)$, ash $(2.38 \%)$ and fat $(5.33 \%)$ content was found in Type-I idli. Storage studies showed that all the three types of idli prepared from 3 months stored instant mixes were found in the category of 'liked moderately' to 'liked slightly' and acceptable up to 90 days of storage. Fat acidity content of all three types of $i d l i$ was found within the permissible limit. It may be concluded that instant $i d l i$ mixes could be stored up to 3 months successfully without any significant change in their sensory attributes.

\section{Introduction}

Celiac disease is an autoimmune inflammatory disease of the small intestine that can occur in genetically predisposed people due to ingestion of gluten (a protein found in wheat, rye and barley (Zannini et al., 2012) which leads to damage in the small intestine villi (small finger like projections). The function of intestinal villi is to promote the nutrient absorption, as the villi get damaged, nutrients cannot be absorbed properly in the body leading to malabsorption of several important nutrients such as iron, folic acid and calcium, fat soluble vitamins and many other manifestations (Jnawali et al., 2016; Tanwar and Dhillon, 2017). Till date the only treatment of people suffering from celiac 
disease is to follow a gluten free diet (RubioTapia et al., 2013). Complete avoidance of gluten enables the intestine to heal, and the nutritional deficiencies and other symptoms to resolve (Dhankar, 2013). A strict adherence to gluten-free diet al., so reduces the risk of developing many of the serious long-term complications related to untreated celiac disease.

However, following a gluten free diet might sound simple but it is not easy, as it not only involves eliminating gluten containing grains and all products that contain them, which requires constant vigilance, but there is also a sense of social isolation and pressure that accompanies the process (Bauman et al., 2008).

The first consideration in the preparation of gluten free product includes the exclusion of any food or food ingredient that contains gluten, as celiac disease is triggered by the ingestion of gluten or its protein fraction. Oat is the only cereal containing a globulin or legume like protein avenalins, as the major $(80 \%)$ storage proteins. It is currently a very popular coarse cereal in consumer demand due to its unique nutritional and health properties (Sharma et al., 2010).

They are generally consumed as whole grains and hence the nutrients present are not lost during processing. They are excellent source of different dietary fibre compound of mixed linkage $\quad(1 \rightarrow 3), \quad(1 \rightarrow 4) \quad \beta$-D glucan, arabinoxylans and cellulose. The incorporation of oats into a gluten free diet diversifies the celiac diet and also provides many health and nutritional benefits (Sharma and Chawla, 2012).

Keeping these facts in view, in the present study five types of oat based value added gluten free instant idli were prepared by using unprocessed and processed instant mixes.

\section{Materials and Methods}

\section{Procurement of selected oat variety}

One oat variety (OS-346) was procured from the Forage Section of the Department of Genetics and Plant Breeding, CCS Haryana Agricultural University, Hisar, whereas rice, mung bean and linseed samples were purchased from local market.

All the samples were cleaned and stored in plastic containers till further use. The oat grain samples were processed by using various processing techniques.

\section{Processing of oat grains}

Different processing methods were used to process the oat grains:

The unprocessed and processed oat grains, rice and mung bean were subjected to milling to obtain flour. Linseed seeds were roasted and ground to obtain fine powder. Roasted oat flour, rice flour, mung bean flour and linseed powder separately in ratio of 60:40:20:5 and then roasted spices (mustard seeds and curry leaves). Added sodium bicarbonate, citric acid, Eno and salt and mixed all the ingredients well. Then packed and sealed in polyethylene pouches.

Reconstituted idli mix (100g) with curd (80g) and water $(30 \mathrm{~g})$ then mix it properly to form a smooth batter. Poured the mixture in greased moulds and microwave for 2-3 minutes.

\section{Organoleptic evaluation of oat based gluten free instant Idli}

Instant idli were subjected to sensory evaluation with respect to color, appearance, aroma, texture, taste and overall acceptability by a panel of 10 semi trained judges, using 9 point hedonic scale. 
Functional and nutritional properties of oat based gluten free instant Idli

On the basis of organoleptic acceptability instant $i d l i$ prepared with unprocessed, malted and flaked oat flour based mix were selected for further nutritional analysis. Water absorption capacity of flours was measured by the method described by Singh and Singh (1991). Oil absorption capacity was done according to the method of Iyer and Singh (1997). For measuring the bulk density, grains were gently filled in a $100 \mathrm{ml}$ graduated cylinder. The bottom of cylinder was gently tapped several times until there was no further diminution of the sample level either filling to the $100 \mathrm{ml}$ mark. Bulk density was calculated as weight of sample per unit volume of sample $(\mathrm{g} / 100 \mathrm{ml})$. The different protein fractions viz., albumin (water soluble), globulin (salt soluble), prolamin (alcohol soluble) and glutelin (alkali soluble) were determined according to the method of AACC (2000). Proximate composition such as moisture, protein, crude fat, crude fibre and ash was determined by employing the standard method of analysis (AOAC, 2000). Total carbohydrates were estimated by the following calculation method: Total carbohydrates $(\%)=$ 100 - (Crude protein+crude fat+crude fibre+ash). Total energy was calculated theoretically by using the following conversion factors $4.0,4.0$ and $9.0 \mathrm{Kcal} / \mathrm{g}$ for protein, carbohydrates and fat, respectively, according to the method described by Paul and Southgate (1979) (Table 4).

\section{Shelf life of most acceptable developed oat based gluten free instant idli}

\section{Sensory evaluation}

Organoleptic evaluation of stored products were done for period of 3 months at interval of one month by a panel of ten semi trained judges for colour, appearance, aroma, texture, taste and overall acceptability using a ninepoint Hedonic Scale.

\section{Fat acidity}

The fat acidity was determined by the standard method of analysis (AOAC, 2000).

\section{Statistical analysis}

Mean, standard error and CD (critical difference) were calculated for analysis of data (Sheoran and Pannu, 1999).

\section{Results and Discussion}

Five types of $i d l i$ developed from instant $i d l i$ mixes which were prepared by addition of 40 per cent rice flour, 20 per cent mung bean flour and 5 per cent linseed powder in 60 per cent unprocessed and processed oat flour. The data on organoleptic acceptability of oat based gluten free instant $i d l i$ is presented in Table 1. Mean scores of colour of five types of idli ranged from 5.25 to 7.60 , respectively. Idli prepared from (Type-I, Type-II, Type-III and Type-IV) instant mixes based on unprocessed, malted, flaked and roasted oat flour fell in the category of 'liked moderately'. Whereas idli prepared from (Type-V) instant mix based on popped oat flour got lowest scores of colour i.e. 5.25 which was 'liked slightly' by the penalists. Mean scores of appearance of all five types of $i d l i$ were 7.72, 7.78, 7.58, 6.99 and 5.90 respectively, with idli prepared from Type-I, Type-II and Type-III instant mixes based on unprocessed, malted and flaked oat flour were found in the category of 'liked moderately'. However, idli which prepared from instant mixes based on (Type-IV and Type-V) roasted and popped oat flour was found to be in the category of 'liked slightly' to 'neither liked nor disliked'. Aroma scores of (Type-I, Type-II and Type-III) idli prepared from instant mixes based on unprocessed, malted and flaked oat flour were 7.18, 7.58 
and 7.27, which were 'liked moderately' by the panelists. However, 6.90 and 6.59 aroma scores were obtained by Type-IV and Type-V $i d l i$ which was 'liked slightly' by the judges. Type-IV and Type-V Idli differed significantly from other three types of idli. Texture scores of Type-I, Type-II, Type-III and Type-IV idli (mixes based on unprocessed, malted, flaked and roasted oat flour) were fell in the category of 'liked moderately'. Whereas the texture of idli prepared with popped oat flour (Type-V) based instant mix (6.60) was 'liked slightly' by the judges. It may be due to the fact that popping of oat grains imparts dryness to the $i d l i$. Taste scores of idli prepared from mixes using unprocessed, malted and flaked oat flour (Type-I, Type-II and Type-III) were 7.25, 7.29 and 7.48 , respectively, which found in the category of 'liked moderately'. However, the taste of roasted and popped oat flour based idli (Type-IV and Type-V) was found in the category of 'liked slightly' to 'neither liked nor disliked'. Overall acceptability scores of all types of idli ranged from 5.95 to 7.53, being highest (7.53) in Type-II idli (malted oat flour based mix) and lowest (5.95) in Type-V idli (popped oat flour based mix).. Overall acceptability scores of idli made from mixes based on unprocessed, malted and flaked oat flour (Type-I, Type-II and Type-III) were found in the category of 'liked moderately' whereas idli made from roasted and popped oat flour (Type-IV and Type-V) based mixes were 'liked slightly' and 'neither liked nor disliked' by the panelists. Sharma et al., (2010) also reported that supplementation with roasted oat flour resulted in decreased sensory scores of idli due to development of dark colour, burnt flavour and taste which are in close agreement with the present results. Water absorption capacity of idli prepared from Type-I instant mix (based on unprocessed oat flour) was $2.17 \mathrm{~g} / \mathrm{g}$, which increased significantly $(\mathrm{P} \leq 0.05)$ in idli prepared from Type-II mix (based on malted oat flour). Whereas, the idli prepared from Type-III mix (based on flaked oat flour) had almost similar $(2.18 \mathrm{~g} / \mathrm{g})$ water absorption capacity as in idli prepared from Type-I mix. Non-significant differences were found between the water absorption capacity of $i d l i$ prepared from Type-I and Type-III mixes. These results are in accordance with Murugkar et al., (2013) who reported that water absorption index and water solubility index increased significantly in germinated mixes indicating the ability of flour to absorb more water. Other workers also reported similar results which are in close agreement with the present results (Ocheme and Chinma 2008; Gernah et al., 2011; Ocheme et al., 2015). Oil absorption capacity of all three types of idli was $1.89,1.93$ and $1.90 \mathrm{~g} / \mathrm{g}$, respectively. Highest (1.93 g/g) was observed in Type-II idli followed by Type-III and Type-I idli prepared from three different instant mixes. Deepali et al., (2013) reported that germination promote/induced oil absorption capacity may be due to solubilization and dissociation of proteins leading to exposure of non-polar constituents from within the protein molecule (Table 2). Ocheme and Chinma (2008); Gernah et al., (2011); Ocheme et al., (2015) also reported similar results which are in agreement of present study. Bulk density was $0.67 \mathrm{~g} / \mathrm{ml}$ in idli prepared from Type-I mix (based on unprocessed oat flour), which declined in idli prepared from Type-II and III mix (based on malted and flaked oat flour). The bulk density was almost similar in Type-I and Type-III idli. The values were 0.67 and $0.68 \mathrm{~g} / \mathrm{ml}$ respectively. The bulk density of idli prepared from Type-I mix differed significantly from idli prepared from Type-II mix. Other workers (Elkhalifa and Bernhardt 2010; Onesmo 2011; Imtiaz and Burhan 2012) also reported that bulk density of products made from malted and flaked millet/pulses flour mixes had lower bulk density than products made from unprocessed millet/pulses mixes. 
Table.1 Mean scores of organoleptic acceptability of oat based gluten free instant idli

\begin{tabular}{|c|c|c|c|c|c|c|}
\hline Instant Idli & Colour & Appearance & Aroma & Texture & Taste & Overall Acceptability \\
\hline Type-I & $7.60 \pm 0.23$ & $7.72 \pm 0.29$ & $7.18 \pm 0.21$ & $7.36 \pm 0.18$ & $7.25 \pm 0.22$ & $7.42 \pm 0.15$ \\
\hline Type-II & $7.61 \pm 0.23$ & $7.78 \pm 0.21$ & $7.58 \pm 0.23$ & $7.41 \pm 0.16$ & $7.29 \pm 0.12$ & $7.53 \pm 0.12$ \\
\hline Type-III & $7.33 \pm 0.14$ & $7.58 \pm 0.19$ & $7.27 \pm 0.11$ & $7.38 \pm 0.13$ & $7.48 \pm 0.16$ & $7.40 \pm 0.08$ \\
\hline Type-IV & $7.13 \pm 0.13$ & $6.99 \pm 0.28$ & $6.90 \pm 0.14$ & $7.00 \pm 0.00$ & $6.80 \pm 0.21$ & $6.96 \pm 0.07$ \\
\hline Type-V & $5.25 \pm 0.58$ & $5.90 \pm 0.52$ & $6.59 \pm 0.14$ & $6.60 \pm 0.22$ & $5.45 \pm 0.38$ & $5.95 \pm 0.17$ \\
\hline CD $(\mathbf{P} \leq 0.05)$ & 0.94 & 0.93 & 0.49 & 0.46 & 0.68 & 0.39 \\
\hline
\end{tabular}

Values are mean \pm SE of ten independent determinations

Type-I: Unprocessed oat flour: Rice flour: Mung bean flour: Linseed powder (60:40:20:5)

Type-II: Malted oat flour: Rice flour: Mung bean flour: Linseed powder (60:40:20:5)

Type-III: Roasted oat flour: Rice flour: Mung bean flour: Linseed powder (60:40:20:5)

Type-IV: Popped oat flour: Rice flour: Mung bean flour: Linseed powder (60:40:20:5)

Type-V: Flaked oat flour: Rice flour: Mung bean flour: Linseed powder (60:40:20:5)

Table.2 Physico-chemical properties of oat based gluten free instant idli (on dry matter basis)

\begin{tabular}{|c|c|c|c|c|}
\hline Instant idli & $\begin{array}{c}\text { Water absorption } \\
\text { Capacity }(\mathrm{g} / \mathrm{g})\end{array}$ & $\begin{array}{c}\text { Oil absorption } \\
\text { Capacity }(\mathrm{g} / \mathrm{g})\end{array}$ & $\begin{array}{c}\text { Bulk } \\
\text { Density }(\mathrm{g} / \mathrm{ml})\end{array}$ & $\begin{array}{c}\text { Gluten } \\
(\mathrm{g} / \mathbf{1 0 0 g})\end{array}$ \\
\hline Type-I & $2.17 \pm 0.02$ & $1.89 \pm 0.01$ & $0.62 \pm 0.01$ & ND \\
\hline Type-II & $2.20 \pm 0.01$ & $1.93 \pm 0.00$ & $0.68 \pm 0.00$ & ND \\
\hline Type-III & $2.18 \pm 0.05$ & $1.90 \pm 0.02$ & 0.04 & ND \\
\hline CD(P<0.05) & 0.02 & 0.03 & - \\
\hline
\end{tabular}

Values are mean \pm SE of three independent determinations $\quad$ ND=Not detected

Type-I: Unprocessed oat flour: Rice flour: Mung bean flour: Linseed powder (60:40:20:5)

Type-II: Malted oat flour: Rice flour: Mung bean flour: Linseed powder (60:40:20:5)

Type-III: Flaked oat flour: Rice flour: Mung bean flour: Linseed powder (60:40:20:5)

Table.3 Protein fractions (\%) of oat based gluten free instant idli (on dry matter basis)

\begin{tabular}{|c|c|c|c|c|}
\hline Instant idli & Albumin & Globulin & Prolamin & Glutelin \\
\hline Type-I & $2.87 \pm 0.02$ & $5.45 \pm 0.18$ & $1.12 \pm 0.01$ & $3.22 \pm 0.02$ \\
\hline Type-II & $3.73 \pm 0.01$ & $6.78 \pm 0.21$ & $0.92 \pm 0.03$ & $3.47 \pm 0.06$ \\
\hline Type-III & $3.60 \pm 0.03$ & $6.32 \pm 0.15$ & $0.99 \pm 0.03$ & $3.33 \pm 0.01$ \\
\hline CD(P $\leq 0.05)$ & 0.04 & 0.12 & 0.03 & 0.06 \\
\hline
\end{tabular}

Values are mean \pm SE of three independent determinations

Type-I: Unprocessed oat flour: Rice flour: Mung bean flour: Linseed powder (60:40:20:5)

Type-II: Malted oat flour: Rice flour: Mung bean flour: Linseed powder (60:40:20:5)

Type-II : Flaked oat flour: Rice flour: Mung bean flour: Linseed powder (60:40:20:5)

Table.4 Proximate composition (\%) and energy (Kcal/100g) of oat based gluten free instant idli (on dry matter basis)

\begin{tabular}{|c|c|c|c|c|c|c|c|}
\hline $\begin{array}{c}\text { Instant } \\
\text { idli }\end{array}$ & Moisture & $\begin{array}{c}\text { Crude } \\
\text { protein }\end{array}$ & $\begin{array}{c}\text { Crude } \\
\text { fibre }\end{array}$ & Assh & $\begin{array}{c}\text { Crude } \\
\text { fat }\end{array}$ & Carbohydrates \\
\hline Type-I & $5.45 \pm 0.11$ & $18.48 \pm 0.52$ & $7.22 \pm 0.17$ & $2.38 \pm 0.09$ & $5.33 \pm 0.05$ & $66.59 \pm 1.66$ \\
\hline Type-II & $6.73 \pm 0.14$ & $18.86 \pm 0.61$ & $6.28 \pm 0.17$ & $2.21 \pm 0.03$ & $4.63 \pm 0.09$ & $68.21 \pm 1.87$ \\
\hline Type-III & $6.39 \pm 0.06$ & $18.61 \pm 0.45$ & $6.31 \pm 0.21$ & $2.02 \pm 0.01$ & $4.68 \pm 0.01$ & $68.19 \pm 1.68$ & $380.00 \pm 2.81$ \\
\hline CD(P $\leq 0.05)$ & 0.61 & NS & 0.56 & 0.11 & 0.28 & 0.92 \\
\hline
\end{tabular}

Values are mean \pm SE of three independent determinations $\quad$ NS=Non-significant

Type-I: Unprocessed oat flour: Rice flour: Mung bean flour: Linseed powder (60:40:20:5)

Type-II: Malted oat flour: Rice flour: Mung bean flour: Linseed powder (60:40:20:5)

Type-III: Flaked oat flour: Rice flour: Mung bean flour: Linseed powder (60:40:20:5) 
Table.5 Effect of storage period on organoleptic characteristics of oat based gluten free instant idli mixes

\begin{tabular}{|c|c|c|c|c|}
\hline Organoleptic characteristics & Storage period (Days) & Type-I & Type-II & Type-III \\
\hline \multirow[t]{4}{*}{ Colour } & 0 & $7.60 \pm 0.23$ & $7.61 \pm 0.23$ & $7.33 \pm 0.14$ \\
\hline & 30 & $7.40 \pm 0.14$ & $7.30 \pm 0.15$ & $7.15 \pm 0.13$ \\
\hline & 60 & $7.35 \pm 0.15$ & $7.25 \pm 0.13$ & $6.90 \pm 0.10$ \\
\hline & 90 & $7.00 \pm 0.00$ & $6.80 \pm 0.13$ & $6.50 \pm 0.16$ \\
\hline Mean & & 7.33 & 7.24 & 6.97 \\
\hline $\mathrm{CD}(\mathrm{P} \leq 0.05)$ & \multicolumn{2}{|c|}{ Storage period $=$ N.S Treatments $=$ N.S } & \multicolumn{2}{|l|}{ Interaction $=$ N.S } \\
\hline \multirow[t]{4}{*}{ Appearence } & 0 & $7.72 \pm 0.29$ & $7.78 \pm 0.21$ & $7.58 \pm 0.19$ \\
\hline & 30 & $7.35 \pm 0.16$ & $7.40 \pm 0.16$ & $7.20 \pm 0.13$ \\
\hline & 60 & $7.15 \pm 0.10$ & $7.30 \pm 0.21$ & $7.00 \pm 0.14$ \\
\hline & 90 & $7.00 \pm 0.14$ & $7.00 \pm 0.00$ & $6.80 \pm 0.13$ \\
\hline Mean & & 7.30 & 7.37 & 7.14 \\
\hline $\mathrm{CD}(\mathrm{P} \leq 0.05)$ & \multicolumn{2}{|c|}{ Storage period $=$ N.S Treatments $=$ N.S } & \multicolumn{2}{|l|}{ Interaction $=1.39$} \\
\hline \multirow[t]{4}{*}{ Aroma } & 0 & $7.58 \pm 0.23$ & $7.18 \pm 0.21$ & $7.27 \pm 0.11$ \\
\hline & 30 & $7.25 \pm 0.13$ & $7.05 \pm 0.05$ & $7.00 \pm 0.00$ \\
\hline & 60 & $7.00 \pm 0.14$ & $6.80 \pm 0.20$ & $6.95 \pm 0.05$ \\
\hline & 90 & $6.25 \pm 0.13$ & $6.00 \pm 0.00$ & $6.00 \pm 0.00$ \\
\hline Mean & & 7.02 & 6.75 & 6.80 \\
\hline $\mathrm{CD}(\mathrm{P} \leq 0.05)$ & \multicolumn{2}{|c|}{ Storage period=N.S Treatments $=$ N.S } & \multicolumn{2}{|l|}{ Interaction $=$ N.S } \\
\hline \multirow[t]{4}{*}{ Texture } & 0 & $7.36 \pm 0.18$ & $7.41 \pm 0.16$ & $7.48 \pm 0.16$ \\
\hline & 30 & $7.00 \pm 0.14$ & $7.00 \pm 0.00$ & $7.00 \pm 0.21$ \\
\hline & 60 & $6.50 \pm 0.16$ & $6.20 \pm 0.13$ & $6.10 \pm 0.10$ \\
\hline & 90 & $6.10 \pm 0.10$ & $6.00 \pm 0.00$ & $6.00 \pm 0.00$ \\
\hline Mean & & 6.74 & 6.65 & 6.64 \\
\hline $\mathrm{CD}(\mathrm{P} \leq 0.05)$ & \multicolumn{2}{|c|}{ Storage period $=$ N.S Treatments $=$ N.S } & \multicolumn{2}{|l|}{ Interaction $=1.35$} \\
\hline \multirow[t]{4}{*}{ Taste } & 0 & $7.25 \pm 0.22$ & $7.29 \pm 0.12$ & $7.48 \pm 0.13$ \\
\hline & 30 & $7.20 \pm 0.13$ & $7.20 \pm 0.13$ & $7.25 \pm 0.13$ \\
\hline & 60 & $7.10 \pm 0.10$ & $7.00 \pm 0.10$ & $6.80 \pm 0.13$ \\
\hline & 90 & $7.00 \pm 0.14$ & $6.90 \pm 0.15$ & $6.70 \pm 0.16$ \\
\hline Mean & & 7.15 & 7.09 & 7.05 \\
\hline $\mathrm{CD}(\mathrm{P} \leq 0.05)$ & \multicolumn{2}{|c|}{ Storage period $=0.65$ Treatments $=$ N.S } & \multicolumn{2}{|l|}{ Interaction $=\mathrm{N} . \mathrm{S}$} \\
\hline \multirow[t]{4}{*}{ Overall acceptability } & 0 & $7.50 \pm 0.12$ & $7.45 \pm 0.09$ & $7.40 \pm 0.08$ \\
\hline & 30 & $7.24 \pm 0.05$ & $7.19 \pm 0.06$ & $7.12 \pm 0.04$ \\
\hline & 60 & $7.02 \pm 0.06$ & $6.91 \pm 0.08$ & $6.75 \pm 0.05$ \\
\hline & 90 & $6.67 \pm 0.04$ & $6.54 \pm 0.03$ & $6.40 \pm 0.05$ \\
\hline Mean & & 7.11 & 7.00 & 6.90 \\
\hline CD $(P<0.05)$ & \multicolumn{2}{|c|}{ Storage period $=0.72$ Treatments $=0.83$} & Interaction $=1.44$ & \\
\hline
\end{tabular}

Values are mean \pm S.E of ten independent determinations

Type-I: Unprocessed oat flour: Rice flour: Mung bean flour: Linseed powder (60:40:20:5)

Type-II: Malted oat flour: Rice flour: Mung bean flour: Linseed powder (60:40:20:5)

Type-III: Flaked oat flour: Rice flour: Mung bean flour: Linseed powder (60:40:20:5)

Table.6 Effect of storage on fat acidity (mg KOH/100g) of oat based gluten free instant $i d l i$ (dry matter basis)

\begin{tabular}{|c|c|c|c|c|}
\hline \multirow{2}{*}{ Instant $\boldsymbol{i d l i}$} & \multicolumn{5}{|c|}{ Storage Period (Days) } \\
\cline { 2 - 5 } & 0 & 30 & 60 & 90 \\
\hline Type-I & $21.68 \pm 0.64$ & $30.40 \pm 0.22$ & $39.60 \pm 0.26$ & $46.41 \pm 0.20$ \\
\hline Type-II & $22.54 \pm 0.28$ & $31.92 \pm 0.53$ & $40.52 \pm 0.36$ & $47.54 \pm 0.35$ \\
\hline Type-III & $22.28 \pm 0.24$ & $31.46 \pm 0.38$ & $40.03 \pm 0.30$ & $47.11 \pm 0.66$ \\
\hline CD $(\mathbf{P} \leq \mathbf{0 . 0 5})$ & & Storage period $=10.53$ & Treatments= 9.12 Interaction=N.S \\
\hline
\end{tabular}

Values are mean \pm SE of ten independent determinations

Type-I: Unprocessed oat flour: Rice flour: Mung bean flour: Linseed powder (60:40:20:5)

Type-II: Malted oat flour: Rice flour: Mung bean flour: Linseed powder (60:40:20:5)

Type-III: Flaked oat flour: Rice flour: Mung bean flour: Linseed powder $(60: 40: 20: 5)$ 


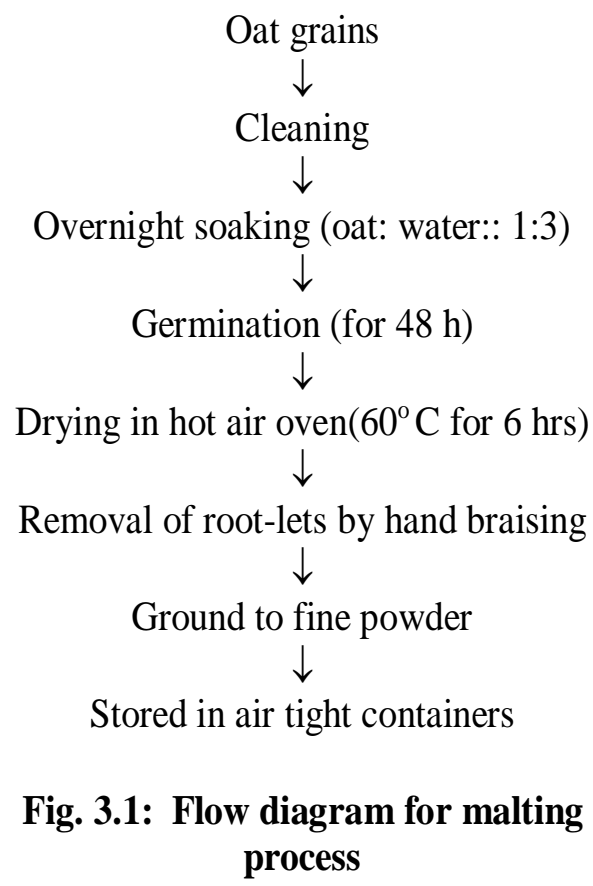

process

Oat grains

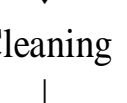

Soaking overnight

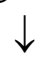

Drying at room temperature

(in open for $12 \mathrm{~h}$ )

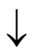

Puffing in traditional furnace using sand

(at $200-250^{\circ} \mathrm{C}$ )

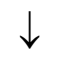

Cooling

$\downarrow$

Ground to fine powder

$\downarrow$

Stored in air tight containers

Fig. 3.3: Flow diagram for popping

process

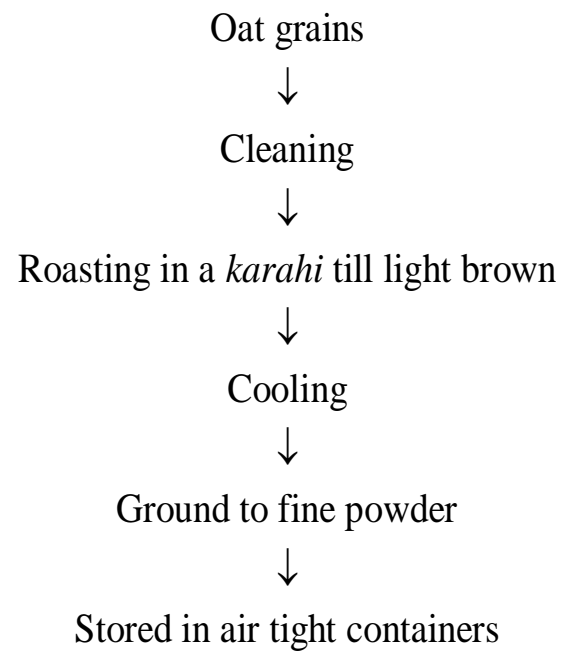

Fig. 3.2: Flow diagram for roasting process

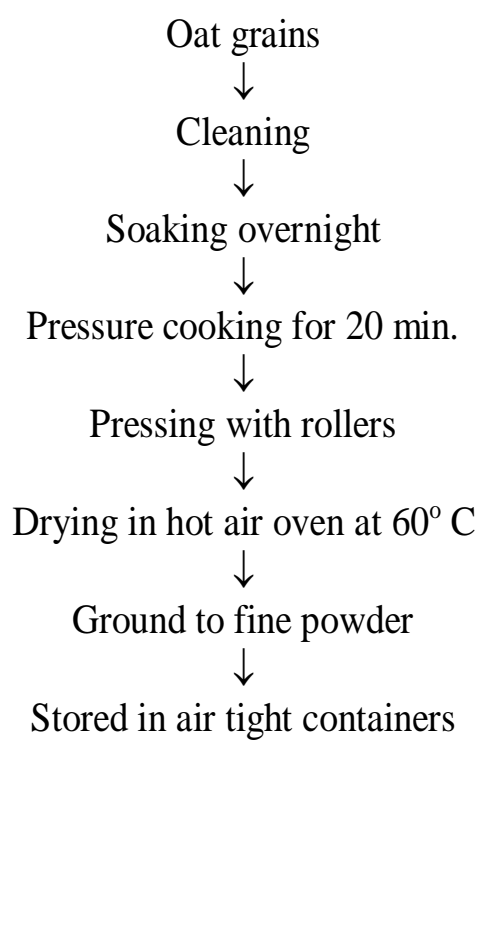

Fig. 3.4: Flow diagram for flaking process 
It might be due to breakdown of complex compounds such as starch and proteins (Ocheme et al., 2015; Takhellambam and Chimmad 2015). Gluten content was not found in any of three instant $i d l i$.

Albumin content was 2.87 per cent in idli which made from Type-I mix and it increased gradually in idli which prepared from Type-II and Type-III mix. Type-II idli had significantly $\quad(\mathrm{P} \leq 0.05) \quad$ higher $\quad(3.73 \%)$ albumin content followed by Type-III (3.63\%) and Type-I (2.87\%) idli. Globulin contents ranged from 5.45 to 6.78 per cent, respectively which were found highest $(6.78 \%)$ in $i d l i$ which prepared from Type-II mix (malted oat flour based mix) and lowest $(5.45 \%)$ in Type-I idli (unprocessed oat flour based mix) (Table 3).

Prolamin content was significantly $(\mathrm{P} \leq 0.05)$ lowest in Type-II and Type-III idli (malted and flaked oat flour based mix) as compared to Type-I idli (unprocessed oat flour based mix). On mean basis, the prolamin content was found highest $(1.12 \%)$ in Type-I idli followed by Type-III (0.99\%) and lowest $(0.92 \%)$ in Type-II idli.

Glutelin content was 3.22 per cent in idli which prepared from mix based on unprocessed (Type-I) oat flour which increased significantly $(\mathrm{P} \leq 0.05)$ with the use of malting and flaking processing methods. Idli which prepared from mixes based on malted (Type-2) oat flour had highest $(3.47 \%)$ content of glutelin content followed by flaked (Type-III 3.33\%) and unprocessed (Type-I $3.22 \%$ ) oat flour. Other workers also reported similar results (Wu 1983; Moneim et al., 2012; Rasane et al., 2015) which are in agreement with the present results.

Moisture content of all the three types of idli ranged from 5.45 to 6.73 per cent, respectively, being highest $(6.73 \%)$ in Type-II idli (malted oat flour based mix) and lowest in Type-I idli (unprocessed oat flour based mix). Protein content of all the three types of $i d l i$ were $18.48,18.86$ and 18.61 per cent, respectively. Protein content was nonsignificantly increased by use of malted and flaked oat flour. Among them, Type-II idli (malted oat flour based mix) had nonsignificantly $\quad(\mathrm{P} \leq 0.05) \quad$ higher $\quad(18.86 \%)$ protein content followed by 18.61 per cent in Type-III idli (flaked oat flour based mix) and 18.48 per cent in Type-I idli (unprocessed oat flour based mix). Crude fibre content of all the three types of idli varied from 6.28 to 7.22 per cent, respectively, with the highest (7.22\%) in Type-I idli and lowest (6.28\%) in Type-II $i d l i$. Type-II and Type-III $i d l i$ differed non-significantly from each other $(\mathrm{P} \leq 0.05)$. Ash content of all the three types of idli ranged from 2.02 to 2.38 per cent, respectively. Ash content of all three types of $i d l i$ differed significantly $(\mathrm{P} \leq 0.05)$. Crude fat content ranged from 4.63 to 5.33 per cent, respectively in three types of idli made from processed (malted and flaked oat flour based mixes) and unprocessed oat flour based mixes. Maximum was observed in Type-I idli and minimum in Type-II idli. Non-significant difference was observed in Type-II and III idli. Similar results were also reported by other workers in products made from malted and unprocessed mixes (Kaushik et al., 2010; Murugkar et al., 2013; Tiwari and Awasthi 2014; Gupta and Brar 2015) who reported that sprouted mixes had significantly higher amount of protein but lower amount of crude fat, crude fibre and ash contents as compared to unprocessed mixes. Giridhar and Sathisha (2016) also reported that there was significant decrease in protein, crude fibre and fat content after flaking of millet grains which are similar as reported in flaked products in the present study. Carbohydrate content of all the three types of idli ranged from 66.59 to 68.21 per cent, respectively. Non-significant difference was observed in carbohydrate 
content of Type-II and Type-III idli. Energy content ranged from 388 to $390 \mathrm{Kcal} / 100 \mathrm{~g}$, respectively in all the three types of idli. Similar results were also reported by earlier workers (Urbano et al., 2005; Laxmi et al., 2015) in processed and unprocessed instant mixes/products.

\section{Shelf life of most acceptable developed value added gluten free products}

\section{Organoleptic evaluation and fat acidity}

Stored products were studied for their sensory characteristics at an interval of 30 days upto acceptability by a panel of 10 semi-trained judges using nine-point Hedonic Scale (Table 5). Three types of $i d l i$ prepared using fresh (0 day) and stored instant idli mixes (Type-I, Type-II and Type-III) (based on unprocessed and processed (malted and flaked) oat flour) were organoleptically evaluated. Mean scores of colour of idli prepared from fresh (0 day) three types of $i d l i$ mixes were 7.60, 7.61 and 7.33 respectively, which fell in the category of 'liked moderately'. These scores decreased non-significantly with increase in storage intervals i.e 30, 60 and 90 days, which found in the category of 'liked moderately' to 'liked slightly'. Similarly, mean scores of appearance of $i d l i$ prepared from fresh (0 day) three types of $i d l i$ mixes were were $7.72,7.78$ and 7.58 which were 'liked moderately' by the panelists. These scores declined as on increasing the storage period up to 3 months and found in the category of 'liked moderately' up to 60 days. However, on 90 days of storage, the appearance of idli prepared from 90 days stored three types of idli mixes were found in the category of 'liked moderately' to 'liked slightly'. Aroma scores of all the three types of idlis developed from fresh (0 day) and $30^{\text {th }}$ day stored idli mixes were 'liked moderately' by the judges. However, the aroma of idli developed from 60 days stored Type-I mix (unprocessed oat flour based mix) fell in the category of 'liked moderately' and idli prepared from 60 days stored Type-II and Type-III idli mixes were 'liked slightly'. The obtained mean scores were $7.00,6.80$ and 6.95 , respectively. Whereas, the aroma of all the three types of idlis were 'liked slightly' on $90^{\text {th }}$ day of storage. Similarly, the texture scores of three types of $i d l i$ prepared from fresh ( 0 day) and 30 days stored idli mixes were 'liked moderately' by the panelists. Whereas, mean scores of texture of idli prepared from 60 and 90 days stored all the three types of $i d l i$ mixes were 'liked slightly' by the judges. Taste scores of idli prepared from fresh (0 day) and 30 days stored three types of idli mixes were found in the category of 'liked moderately' However, the taste scores of idli prepared from 60 and 90 days stored idli mixes were found in the category of 'liked moderately' to 'liked slightly'.

Overall acceptability mean scores of idli prepared from fresh (0 day) Type-I, Type-II and Type-III idli mixes were 7.50, 7.45 and 7.40 , respectively which decreased significantly with increase in storage period i.e., 30, 60 and 90 days. However, overall acceptability scores of idli prepared from stored Type-I (7.67) Type-II (6.54) and TypeIII (6.40) idli mixes were still found in the acceptable category even up to 90 days of storage, might be due to low moisture content. Fat acidity content of $i d l i$ prepared from fresh (0 day) stored idli mix (Type-I) had $21.68 \mathrm{mg}$ $\mathrm{KOH} / 100 \mathrm{~g}$. Whereas, 22.54 and $22.28 \mathrm{mg}$ $\mathrm{KOH} / 100 \mathrm{~g}$ were found in idli prepared from fresh (0 day) stored Type-II and Type-III idli mixes. These were found to be increased with increase in storage interval. The values were $30.40,39.60$ and $46.41 \mathrm{mg} \mathrm{KOH} / 100 \mathrm{~g}$ in idli prepared from 30, 60 and 90 days stored idli mixes. Whereas, fat acidity content i.e 31.92, 40.52 and $47.54 \mathrm{mg} \mathrm{KOH} / 100 \mathrm{~g}$ in idli prepared from 30, 60 and 90 days stored Type-II idli mix and 31.46, 40.03 and 47.11 
$\mathrm{mg} \mathrm{KOH} / 100 \mathrm{~g}$ in idli prepared from 30, 60 and 90 days stored Type-III idli mix, respectively. All these values were found within the permissible limit (Table 6).

From the present study it can be concluded that there is great scope for utilization of unprocessed and processed (malted and flaked oat flour based mix) oat flour to develop value added gluten free instant idli mix for celiac disease patients having good shelf life.

\section{References}

A.A.C.C. 2000. Approved Methods of Analysis. The American Association of Cereal Chemists, St. Paul, MN.

A.O.A.C. 2000. Approved Methods of Analysis. $16^{\text {th }}$ Ed. Association of Official Analytical Chemists. Arlyngton, Verginia, USA.

Bauman, E., J. Friedlander, Gluten sensitivity: a rising concern, 2008.http://citeseerx.ist.psu.edu/viewdo c/download?doi=10.1.1.698.9621\&rep $=$ rep1\&type $=$ pdf $($ accessed 16.08.03).

Dhankar, P. 2013. A study on development of coconut based gluten-free cookies. International Journal of Engineering Science Invention. 2(12): 1-9.

Elkhalifa, A.E.O. and Bernhardt, R. 2010. Influence of grain germination on functional properties of sorghum flour. Food Chemistry. 121: 387-392.

Gernah, D. I., Ariahu, C. C. and Ingbian, E. K. 2011. Effects of malting and lactic fermentation on some chemical and functional properties of maize (Zea mays). American Journal of Food Technology, 6:404-412.

Giridhar, G. and Sathisha, G.J. 2016. Effect of extrusion and flaking on the retention of nutrients and phenolic compounds in millet grains. International Journal of Food Science and Nutrition. 1(4): 0811.
Gupta, S. and Brar, J. 2015. Formulation and evaluation of malted ingredient mixes. International Journal of Food and Nutrition Sciences. 5(3): 182-90.

Imitiaz, H. and Burhan, U.M. 2012. Optimization effect of germination on functional properties of wheat flour by response surface methodology. International Research Journal of Plant Science. 3(3): 31-37.

Iyer, L. and Singh, U. 1997. Functional properties of wheat and chickpea composite flours. Food Australia.49: 27-31.

Jnawali, P., Kumar, V. and Tanwar, B. 2016 Celiac disease: Overview and considerations for development of gluten free foods. Food Science and Human Wellness. 5: 169-176.

Kaushik, G., Satya, S. and Naik S.N. 2010. Effect of domestic processing techniques on the nutritional quality of the soybean. Mediterranean Journal of Nutrition and Metabolism. 3(1): 39-46.

Laxmi, G., Chaturvedi, N. and Richa, S. 2015. The impact of malting on nutritional composition of foxtail millet, wheat and chickpea. Journal of Nutrition and Food Sciences. 5(5): 1-3.

Moneim, A.E., Afify, M.R., El-Beltagi, H.S., Samiha, M., Salam, A.E. and Omran, A.A. 2012. Protein solubility, digestibility and fractionation after germination of sorghum varieties. Plos One. 7(2):1-5.

Murugkar, D.A., Gulati, P. and Gupta, C. 2013. Effect of sprouting on physical properties and functional and nutritional components of multi-nutrient mixes. International Journal of Food and Nutritional Sciences. 2: 8-15.

Ocheme, O. B., Adedeji, O. E., Lawal, G. and Zakari, U. M. 2015. Effect of germination on functional properties and degree of starch gelatinization of 
sorghum flour. Journal of Food Research. 4(2): 159-65.

Ocheme, O.B. and Chinma, C. E. 2008. Effects of soaking and germination on some physico-chemical properties of millet flour for porridge production. Journal of Food Technology. 6(5): 18518.

Onesmo, N.O. 2011. Effect of malting and fermentation on the composition and functionality of sorghum flour. Dissertation in Food Science \& Technology. http://digitalcommons.unl.edu./ foodscidiss/ 12 .

Paul, A. and Southgate, A.D. 1979. The composition of food. $4^{\text {th }}$ Edition, Elsevier North, Holland Biomedical Press, Amestrdam. pp, 5-11.

Rasane, P., Jha, A., Sabikhi, L., Kumar, A. and Unnkrishnan, V.S. 2015. Nutritional advantages of oats and opportunities for its processing as value added foods - a review. Journal of Food Science and Technology. 52, 662-75.

Rubio-Tapia, A., Hill, I.D., Kelly, C.P., Calderwood, A.H. and Murray, J.A. 2013. ACG clinical guidelines: diagnosis and management of celiac disease. American Journal of Gastroenterology. 108: 656-676.

Sharma, V. and Chawla, P. 2012. Development and nutritive evaluation of oat supplemented products for celiac disease. Journal of Dairying Foods and Home Sciences. 31: $112-116$.

Sharma, V., Chawla, P. and Grover, K. (2010) Organoleptic characteristics and nutrient composition of oats supplemented products. Journal of
Research. Punjab Agricultural University. 47: 173-175.

Sheoran, O.P. and Pannu, R.S. 1999. Statistical package for agricultural works. "O.P. Stat" Collage of Agriculture, Kaul, CCS HAU, Hisar.

Singh, U. and Singh, B. 1991.Functional properties of sorghum-peanut composite flour. Cereal Chemistry. 68(5): 460463.

Takhellambam, R.D. and Chimmad, B.V. 2015. Study on physico-functional and nutrient composition of ready-to-cook (RTC) millet flakes. Asian Journal of Home Science. 10(2): 327-331.

Tanwar, B. and Dhillon, M. 2017 Preparation and nutritional quality evaluation of gluten-free cookies. Asian Journal of Dairy and Food Research, 36(1): 63-66.

Tiwari, N. and Awasthi, P. 2014. Effect of different processing techniques on nutritional characteristics of oat (Avena sativa) grains and formulated weaning mixes. Journal of Food Science and Technology. 51: 2256-2259.

Urbano, G., Lopez, T., Porres, J.M., Gomezvillalvaa, E. and Frias, J. 2005. Nutritional assessment of raw and germinated Pea. Scientific Research and Essays. 9(4), 52-59.

Wu, Y.V. 1983. Effect of germination on oats and oat protein. Cereal Chemistry. 60(6): 418-420.

Zannini, E., Pontonio, E., Waters, DM. and Arendt, E.K. 2012. Applications of microbial fermentations for production of gluten-free products and perspectives. Applied Microbiology Biotechnology, 93: 473-485.

\section{How to cite this article:}

Bhawna Mehta and Sudesh Jood. 2018. Organoleptic Acceptability, Nutritional Properties and Shelf Life of Oat Based Gluten Free Instant idli. Int.J.Curr.Microbiol.App.Sci. 7(03): 17771787. doi: https://doi.org/10.20546/ijcmas.2018.703.209 